\title{
RAINFALL EROSIVITY IN THE UPPER LLOBREGAT BASIN, SE PYRENEES
}

\author{
G. CATARI ${ }^{1,2, *} \&$ F. GALlaRT ${ }^{2}$ \\ 1 Institute of Environmental Sciences and Technology (ICTA), Autonomous University of Barcelona \\ (UAB), Barcelona, Spain. \\ 2 Institute of Environmental Assessment and Water Research (IDÆA), CSIC. Barcelona, Spain \\ gcatari@ija.csic.es
}

\begin{abstract}
The aim of this study was to determine the spatial distribution of rainfall erosivity in a $504 \mathrm{~km}^{2}$ river basin in Eastern Pyrenees and assess its uncertainties. The study area is topographically complex and is dominated by Mediterranean climate with intense rains during summer. Available rainfall dataset includes 14 years spanning from 1991 to 2004 at daily resolution from seven weather stations and sub-hourly from one station. Daily $R$ values were calculated from sub-hourly data, and then by using the relationship between daily $R$ values and precipitation, the $R$ values for weather stations having only daily rainfall resolution were calculated. The error propagation by using such upscaling approach was analyzed. The studied sources of uncertainty of $R$ factor at annual scale were: the use of the relationship between daily $R$ values and precipitation, the temporal averaging of $R$ values and spatial variation. Results have shown that at annual scale the temporal averaging was the largest contributor of uncertainty (70\%); however this contribution decreased significantly (14\%) when $R$ was estimated for the long term.
\end{abstract}

Keywords: R factor; error propagation; RUSLE; Pyrenees; Upper Llobregat Basin.

RESUMEN.- El objetivo de este estudio fue determinar la distribución espacial de la erosividad de precipitación en una cuenca de $504 \mathrm{~km}^{2}$ en el Este de los Pirineos y evaluar sus incertidumbres. El área de estudio presenta una topografía compleja y está dominada por un clima Mediterráneo con lluvias intensas durante el verano. Los datos de precipitación utilizados abarcan 14 años, desde 1991 hasta 2004, a una resolución diaria en siete estaciones meteorológicas y minutal en una estación. Los valores diarios de $R$ se calcularon a partir de datos con resolución minutal, y luego se estableció una relación entre valores diarios de $R$ y precipitación, con el fin de calcular los valores de $R$ para las estaciones meteorológicas que sólo presentan resolu- 
ción diaria. Las fuentes de incertidumbre considerados para el factor $R$ a escala anual fueron: el uso de la relación entre los valores de $R$ diaria y precipitación, el promedio temporal de los valores de $R$ y la variación espacial. Los resultados han mostrado que a escala anual la variación temporal fue el mayor contribuyente (70\%) a la incertidumbre total, sin embargo éste disminuyó significativamente $(14 \%)$ cuando $R$ fue estimada a largo plazo.

Palabras clave: Factor R; propagación de error; RUSLE; Pirineos; Cuenca Alta del Llobregat.

\section{Introduction}

Uncertainty is unavoidable to some degree especially when it comes to environmental issues such as soil erosion, mainly because of system complexity, spatial heterogeneity and scarcity of data. Soil erosion is a recognized environmental problem, and its primarily driving force is rainfall because of the erosive forces of raindrop impact on soil surface (ELLISON, 1952) and generation of surface runoff (MOORE, 1979). Estimation of rainfall erosivity in large areas is often based on simplification of processes and scaling techniques, in these processes error in data and methods may be propagated into results which need to be quantified in order to give value to estimations in decision-making.

HUDSON (1995) identified three attributes of rain related to erosion (a) rainfall intensity, which is highly variable in time and space, (b) rainfall duration, and (c) rainfall kinetic energy. Rainfall kinetic energy and intensity are the most commonly used to predict soil detachment, the relationship between the two is complex since depends on the raindrop size.

Rainfall-runoff erosivity index is a basic component of empirical soil erosion models such as when modeling rill and interrill erosion with RUSLE (WISCHMEIER \& SMITH, 1959; RENARD et al., 1997). Within RUSLE it is known as the rainfall-runoff erosivity factor ( $\mathrm{R}$ factor), which is defined as the product of total kinetic energy of a rainfall event and its maximum 30-minute rainfall intensity (RENARD et al., 1997). To compute the $R$ factor it is recommended at least 20 years of rainfall intensity data at sub-hourly resolution (WISCHMEIER \& SMITH, 1978).

Usually sub-hourly rainfall data is not always readily available; instead, downscaling approaches are used such as from daily, monthly or annual resolution. For instance DE SANTOS LOUREIRO \& AZEVEDO COUTINHO (2001) estimated the rainfall-runoff erosivity index using monthly data in Portugal; in Italy DIODATO (2004) developed a method for using annual 
data, obtaining satisfactory results. However, upscaling approaches may also be used when there are available sub-hourly data in one or a few weather stations and erosivity values are needed for larger areas. In the latter case, relationships at a given point are extrapolated to other locations having coarse data resolution. In both extrapolation and upscaling approaches, large errors may be expected, which need to be assessed.

The temporal scale at which the rainfall erosivity becomes interesting depends on the end-user, for instance farmers might be interested in knowing the annual $\mathrm{R}$ for a given year and often at small scale, and on the contrary land use planners might find more useful long term $R$ values and at larger scale.

Although patterns of rainfall erosivity pattern have been studied in the NE Spain especially in the Ebro Basin (LÓPEZ-VICENTE et al., 2008; ANGULO-MARTINEZ et al., 2009), there is scarce information for the Eastern Pyrenees and error propagation analysis for rainfall erosivity is scarcely performed. The Eastern Pyrenees present high relief, this complex topographical organization can encourage the generation of isolated extreme rainfall events (GARCIA-RUIZ et al., 2000) which can strongly affect values and may be important contributors to uncertainty.

This article deals with the assessment of uncertainty of rainfall erosivity due to diverse sources in an area of the Eastern Pyrenees, using simple statistical analyses. The specific objectives are (a) to obtain the average annual $\mathrm{R}$ factor for each weather station and for the whole Upper Llobregat Basin, and (b) to define the magnitude of error due to up-scaling method, and temporal and spatial variations at both the weather station and Upper Llobregat Basin levels.

\section{Materials and methods}

\subsection{Study area}

The study area is located in the Eastern Pyrenees, in the headwaters of Llobregat River (Fig. 1). It comprises $504 \mathrm{~km}^{2}$, this area constitutes a mountainous rangeland with a highly contrasted relief (elevation varies between $627 \mathrm{~m}$ and $2540 \mathrm{~m}$ a.s.l.) where the average slope is $24^{\circ}$ (CATARI, 2009). The climate is Mediterranean with a mean annual precipitation of 862 $\pm 206 \mathrm{~mm}$, with a mean of 90 rainy days per year, with intense summer storms; the mean annual temperature is $9.1^{\circ} \mathrm{C}$ (GALLART et al., 2002). 


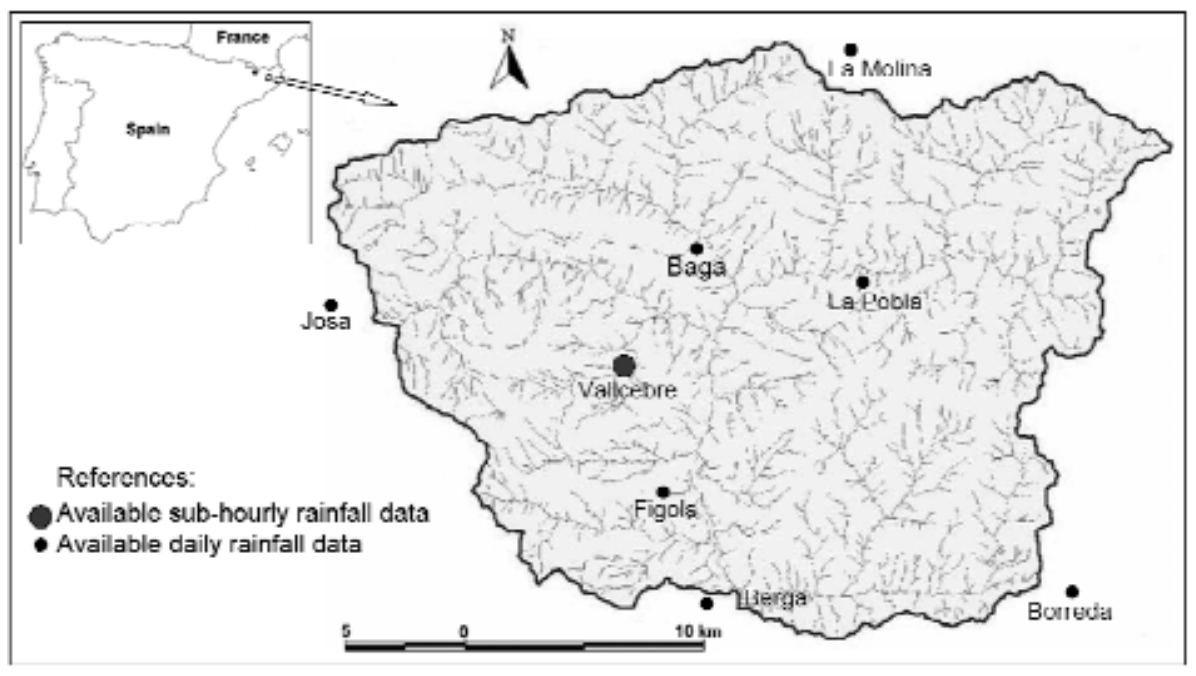

Figure 1. Location of weather stations in and nearby the study area.

\subsection{Rain gauge network}

Rainfall dataset was available from seven weather stations, which was provided by the Spanish National Meteorological Institute (INM). Four stations are within the limits of the study area and four nearby; these stations are located at a wide range of altitudes. The coordinates of their location and altitude are shown in Table 1. Another station (Vallcebre) belongs to the Surface Hydrology and Erosion Research Group at IDAEA, CSIC and presented sub-hourly resolution (often 15 minutes), while the remainder seven stations had only daily resolution.

\subsection{Determination of $R$ and error propagation analyses}

The rainfall erosivity for the Upper Llobregat Basin was computed in two stages. Firstly, annual and seasonal relationships between daily rainfall erosivity (dependent variable) and daily rainfall depth (predictor) for the station with sub-hourly data (Vallcebre) were developed. Then these relationships were applied to stations having only daily resolution. 
RAINFALL EROSIVITY IN THE UPPER LLOBREGAT BASIN, SE PYRENEES

Table 1. Location of weather stations in or nearby the Upper Llobregat Basin.

\begin{tabular}{|lcccc|}
\hline Weather station & INM Code & UTM $(x)$ & UTM $(y)$ & Altitude m a.s.l. \\
\hline La Molina & 585 & 412463 & 4687479 & 1680 \\
Josa Tuixen & $632 \mathrm{o}$ & 381765 & 4676545 & 1184 \\
La Pobla & $78 \mathrm{u}$ & 413296 & 4677011 & 808 \\
Baga & 82 & 406006 & 4678709 & 795 \\
Vallcebre & $84 \mathrm{i}$ & 402375 & 4673051 & 1133 \\
Figols & $85 \mathrm{a}$ & 405773 & 4669858 & 754 \\
Berga & $92 \mathrm{c}$ & 404520 & 4662070 & 664 \\
Borreda & 99 & 421212 & 4665411 & 845 \\
\hline
\end{tabular}

Source: Delgado (2006) and INM (2004).

\subsubsection{Vallcebre}

Rainfall dataset for the period 01 January 1994 to December 2005 was used. Since the annual $\mathrm{R}$ factor must be determined from daily $\mathrm{R}$ values, the rainfall depth dataset of each event were split into daily precipitation, considered as the 24 hour period counted from 8:00 am until 8:00 am of the next calendar-day.

The erosive events (days) were selected according to RUSLE guidelines, which is, an event is erosive if the cumulative rainfall is greater than $12.5 \mathrm{~mm}$, or if the $15 \mathrm{~min}$ intensity is greater than $6.25 \mathrm{~mm}$. Calculation has involved the analysis of the hyetograph of every rainfall event in order to create an erosive events database, which was comprised of 211 daily rainfall episodes.

The $\mathrm{R}$ factor indicates that when factors other than rainfall are held constant, soil losses from cultivated fields are directly proportional to the multiplication of the total storm energy (E) times the maximum 30-min intensity (I30). The R factor in MJ mm ha- ${ }^{-1} \mathrm{~h}^{-1} \mathrm{day}^{-1}$ was calculated from Eq. 1 (WISCHMEIER \& SMITH, 1978),

$$
\left.R=\sum_{k=1}^{m}\left(E I_{30}\right)_{k} \quad \text { (Eq. } 1\right)
$$

Where EI30 is the rainfall erosivity index for storm $k, m$ is the number of storms in a day. The total storm kinetic energy $\mathrm{E}_{k}\left(\mathrm{MJ} \mathrm{ha}^{-1}\right)$ was obtained by Eq. 2 (MCGREGOR et al., 1995; FOSTER, 2004), where $p k$ and $i k$ are, the rainfall depth $(\mathrm{mm})$ and rainfall intensity $\left(\mathrm{mm} \mathrm{h}^{-1}\right)$ respectively for rainfall periods in which intensity was considered constant.

$$
E_{k}=p_{k} 0.29\left[1-0.72 \exp \left(-0.082 i_{k}\right)\right] \quad \text { (Eq. 2) }
$$


In Vallcebre, rainy seasons typically are autumn and spring; however during summer short intense convective storms provide significant rainfall amounts (LATRON et al., 2003). In order to determine whether the degree of variability is reduced by using separate regressions for summer (61 out of 211) and rest of the seasons (150 out of 211) an ANOVA test for regression was performed. This test has shown that variability is better explained when developing separate equations are developed for each group $(F=310.4, p<$ 0.05).

$\mathrm{R}$ factor values were computed by using equations 1 and 2 . Then using the empirical relationship between daily $R$ and daily rainfall, two linear regressions were developed. The scatter plots showing the relationship between these variables are illustrated in Fig. 2a for summer and in Fig. 2b for the rest of seasons. These regressions are shown in Eq. 3 for summer and Eq. 4 for the rest of the seasons, where $\mathrm{P}$ is rainfall depth in $\mathrm{mm}$.

$$
\begin{array}{lll}
R=-150.14+12.60 P & \mathrm{R}^{2}=0.70 & \mathrm{n}=61 \\
R=-23.48+2.54 P & \mathrm{R}^{2}=0.60 & \mathrm{n}=150
\end{array}
$$

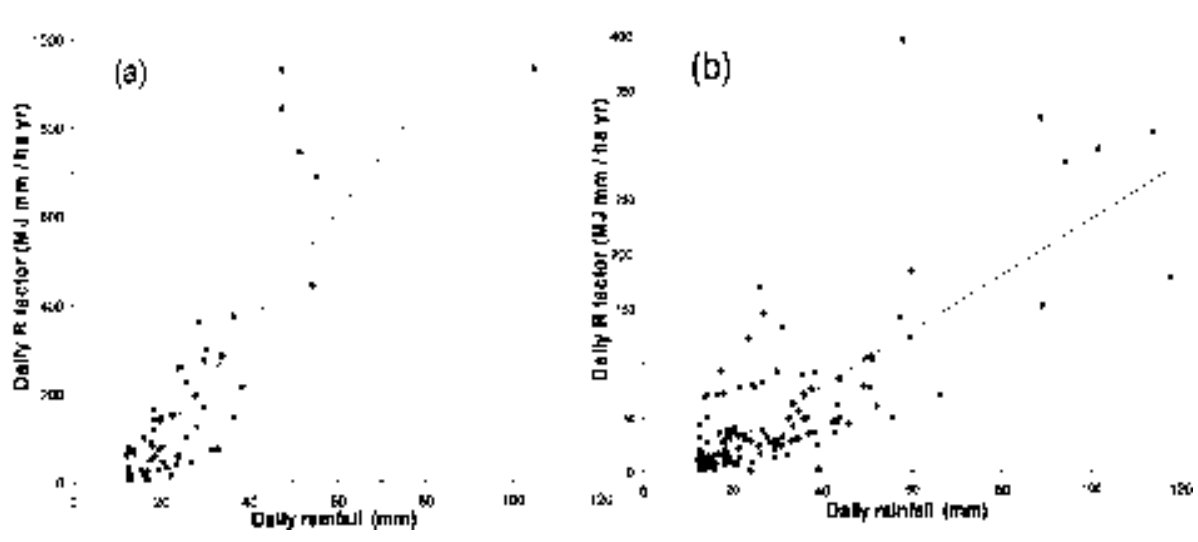

Figure 2. Scatter plots of daily R factor vs. daily rainfall for the Vallcebre weather station: (a) summer, and (b) rest of seasons.

\subsubsection{Upper Llobregat Basin}

The $\mathrm{R}$ factor values for rest of the seven stations given in Table 1, were calculated by substituting $P$ in equations 3 and 4 with daily rainfall in order to calculate the point $R$ values. The area of coverage of each station to the 
river basin was defined by obtaining Thiessen polygons, where any point at random within the polygon has a constant $R$ value. Finally, the $R$ value for the entire basin was obtained by weighing the $\mathrm{R}$ value of each station according to the area of the polygon.

\subsubsection{Error analyses}

A first uncertainty source comes by the fact that $\mathrm{R}$ factors were estimated for a series of rainfall stations with daily records, using the relationships (regressions) between daily rainfall and the $\mathrm{R}$ factor for the storms in that day at Vallcebre. When the values of mean annual $R$ factors from these stations are to be used for estimating soil erosion hazards, it is necessary to estimate the uncertainty of these values.

The uncertainty in these determinations for the whole river basin comes from three sources: (1) the spurious errors of the daily $R$ estimates using the regressions (variance of $\mathrm{R}$ factor not explained by the daily precipitation), (2) the temporal variability (interannual variability of the precipitation), and (3) the spatial variability if $R$ is estimated for the entire river basin.

To find the uncertainty of $R$ factor estimates, first it was estimated the uncertainty (variance or mean square error) of every daily $R$ value calculated from the daily precipitation, which is the square of the standard error of the corresponding regression used to estimate R from P (Eq. 3 and 4). Since the annual $R$ value at a station level is the sum of the $R$ values for every rainy day; the uncertainty of the value (variance) may be found as the sum of the variances of the daily estimates. Second, since the interannual $R$ value is the average of the annual $R$ estimates; the time variability would be the variance of these estimates. Third, the spatial variability is obtained by weighing the deviation of every $R$ value from the mean in function of the relative area of the respective Thiessen's polygon. Finally, the total uncertainty of $R$ estimate was obtained from the sum of regression, time and spatial variances.

It should be noted that when $R$ values are estimated at the annual scale, its uncertainty is calculated as described previously; nevertheless when R is calculated for the long term, its uncertainty due to the temporal source should be calculated by using the variance of the mean. The variance of $R$ factor at annual scale is more useful to farmers, and at the long term scale it is more useful to land use planners. 


\section{Results}

\subsection{Vallcebre}

The annual average $\mathrm{R}$ factor calculated for Vallcebre was $1493 \mathrm{MJ} \mathrm{mm} \mathrm{ha}{ }^{-1}$ $\mathrm{yr}^{-1}$ and the standard error of the mean $277 \mathrm{MJ} \mathrm{mm} \mathrm{ha}{ }^{-1} \mathrm{yr}^{-1}$. The annual $\mathrm{R}$ values for the period 1994 and 2005 are illustrated in Fig. 3. $R$ values are over $2000 \mathrm{MJ} \mathrm{mm} \mathrm{ha} \mathrm{yr}^{-1}$ for 1995, 1996 and 1999; and the lowest values were between 2000 and 2003.

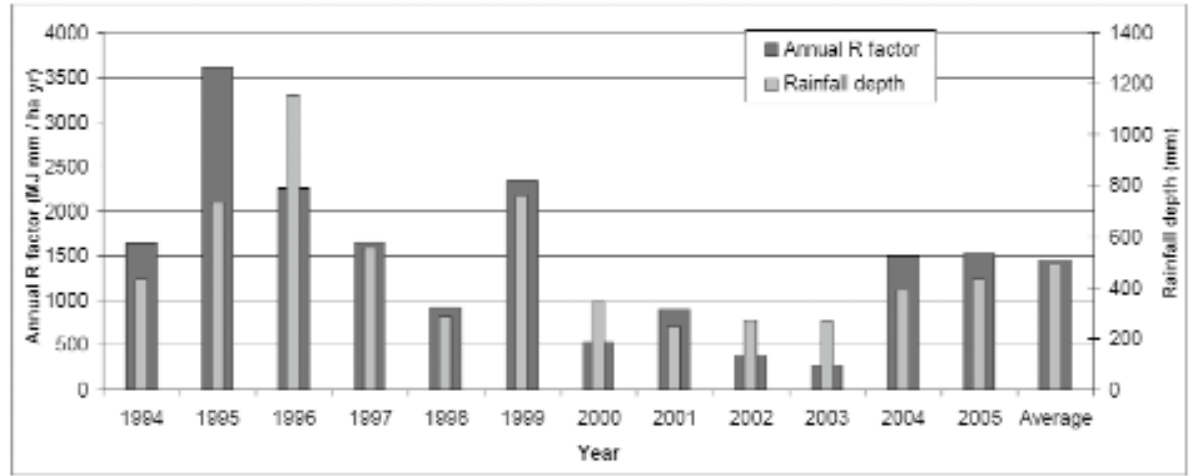

Figure 3. Rainfall depth and $R$ factor values for Vallcebre weather station.

A large rainfall amount (depth) does not necessarily indicate a large $R$ value; it was found that rainfall intensity is the primary driving force. For instance, for 1995 the $\mathrm{R}$ factor value was proportionally very large in relation to the amount of rainfall fallen during that year, where three daily rainfall events contributed almost half to the $\mathrm{R}$ factor, these events are characterized by high intensity and they occurred during summer. On the contrary, the $\mathrm{R}$ factor value for 1996 was proportionally smaller than the amount of rainfall, where 37 daily rainfall episodes were recorded (the year with the largest amount of episodes) but they had a relatively low intensity. This shows that high intensity of infrequent rainfall events strongly disrupt the direct proportionality between rainfall and erosivity factor. 


\subsection{Upper Llobregat Basin}

The average $\mathrm{R}$ factor for all weather stations ranged from 1416.8 to 2496.2 $\mathrm{MJ} \mathrm{mm} \mathrm{ha}{ }^{-1} \mathrm{yr}^{-1}$. The stations with the highest standard error of the mean are Figols and Josa, on the contrary Baga and Berga present the lowest variability as shown in Fig. 3 and Table 2. A clear spatial distribution of the $\mathrm{R}$ factor can be observed, there is more rainfall erosivity in the NE and SE of the basin than in the $\mathrm{W}$.

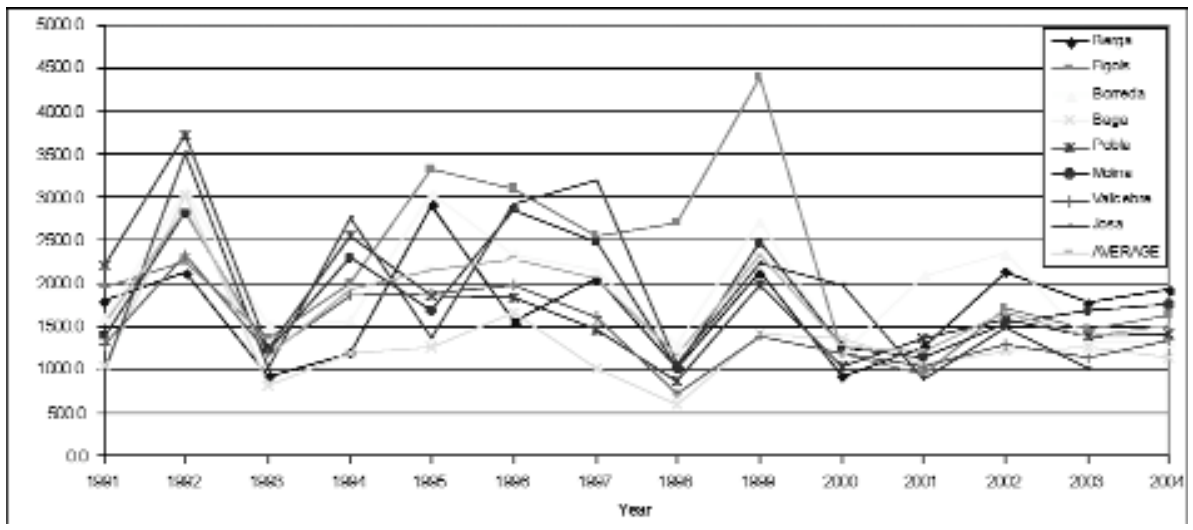

Figure 4. Annual $R$ factor values for each weather station for the period 1991-2004.

The temporal variation of $\mathrm{R}$ factor reveals that, in general, years with heavy rainy days present a more spread distribution of $R$ factor values between weather stations; on the other hand, years with small and low intensity episodes present a relatively more uniform spatial distribution. For example, during 1999 the $\mathrm{R}$ factor value between stations varied largely, where Figols and Borreda (both located in the SE) present the highest values. This is in agreement with the statement that the $\mathrm{R}$ factor values vary with the individual storm precipitation patterns and amount of rainfall (Elliot, 1995b).

The standard errors of the regressions which were developed using dataset from Vallcebre were 150.1 and 40.5 for summer and rest of seasons respectively. 
G. CATARI \& F. GALLART

Table 2. Average $R$ factor values and related uncertainties at the weather station level, and at annual scale (RMSE (root mean square error).

\begin{tabular}{|cccccc|}
\hline Weather station & Area $\left(\mathrm{km}^{2}\right)$ & Average $R$ & Temporal RMSE & Regression RMSE & $\begin{array}{c}\text { Total } \\
\text { RMSE }\end{array}$ \\
\hline JosA & 3.4 & 2,131 & 1,107 & 406 & 1,179 \\
Molina & 106.8 & 2,023 & 714 & 440 & 839 \\
Pobla & 125.1 & 1,971 & 918 & 464 & 1,028 \\
Baga & 107.0 & 1,417 & 676 & 407 & 789 \\
Borreda & 39.5 & 2,236 & 813 & 448 & 928 \\
Figols & 86.9 & 2,496 & 1,168 & 468 & 1,259 \\
Berga & 19.6 & 1,828 & 645 & 393 & 755 \\
Vallcebre & 15.9 & 1,493 & 914 & 311 & 965 \\
\hline
\end{tabular}

The average annual $\mathrm{R}$ factor values for the Upper Llobregat basin was 1956.1 MJ mm ha ${ }^{-1} \mathrm{yr}^{-1}$. The estimated $\mathrm{R}$ value is larger than the value estimated for the NE by USON \& RAMOS (2001) which was $1400 \mathrm{MJ} \mathrm{mm} \mathrm{ha}^{-1}$ $\mathrm{yr}^{-1}$ although that value was calculated for a single year (1996). The uncertainty of this value was calculated for two temporal resolutions. The first case, when in the temporal variability source, the interannual variability of $R$ value is considered. The second case, is when the interannual variability is obtained from the variance of the mean.

For the first case, the weighted temporal variability in function of area represents $70 \%$, the weighted regression variability represents $18 \%$ and the weighted spatial variability represents only $12 \%$ (Table 2 ). Therefore the $\mathrm{R}$ factor value and uncertainty for this case can be written as 1956.1 $\pm 1035.4 \mathrm{MJ}$ $\mathrm{mm} \mathrm{ha}^{-1} \mathrm{yr}^{-1}$.

For the second case, the magnitude of total uncertainty is smaller than for the first case. The weighted temporal variability is significantly reduced to $14 \%$, the weighted variability of regression although is the same as for the first case, it proportionally increases to $52 \%$. Similarly, the weighted spatial variability also increases in proportion to $34 \%$. The $\mathrm{R}$ factor value and uncertainty for this case can be summarized as $1956.1 \pm 611.7 \mathrm{MJ} \mathrm{mm} \mathrm{ha}^{-1} \mathrm{yr}^{-1}$ (Table 4). 
RAINFALL EROSIVITY IN THE UPPER LLOBREGAT BASIN, SE PYRENEES

Table 3. Average $R$ factor values and related uncertainties at the weather station level and at long term scale (SEM (standard error of the mean)).

\begin{tabular}{|cccccc|}
\hline Weather station & Area $\left(\mathrm{km}^{2}\right)$ & Average $R$ & Temporal SEM & Regression RMSE & $\begin{array}{c}\text { Total } \\
\text { RMSE }\end{array}$ \\
\hline JosA & 3.4 & 2,131 & 307 & 406 & 509 \\
Molina & 106.8 & 2,023 & 191 & 440 & 480 \\
Pobla & 125.1 & 1,971 & 245 & 464 & 525 \\
Baga & 107.0 & 1,417 & 181 & 407 & 446 \\
Borreda & 39.5 & 2,236 & 217 & 448 & 498 \\
Figols & 86.9 & 2,496 & 312 & 468 & 562 \\
Berga & 19.6 & 1,828 & 172 & 393 & 429 \\
Vallcebre & 15.9 & 1,493 & 264 & 311 & 408 \\
\hline
\end{tabular}

\section{Discussion and conclusions}

According to RUSLE guidelines, $\mathrm{R}$ factor is the result of averaging annual values of $R$ factor in a given station. In the Eastern Pyrenees, it was found that the temporal variability is the main contributor of error $(70 \%)$ to total uncertainty, when the annual variability is considered (farmer's perspective), because the $R$ values are associated to a high interannual variation within the same station, on the contrary extrapolation method (linear regressions) and spatial variability are relatively low.

At the long term resolution (land use planner's perspective), the magnitude of error contributed to the total uncertainty by the use of regression becomes the largest (52\%), compared to temporal and spatial variabilities, which are $34 \%$ and $14 \%$ respectively.

\section{Acknowledgments}

This research was supported by the PROBASE (CGL2006-11619). The authors are indebted to: Montserrat Soler and Juliana Delgado and the other members of the Surface Hydrology and Erosion Research Group at IDAEA, CSIC for providing the necessary data and support. The contribution of the first author was made possible by a DEBEQ grant, funded by the Autonomous Government of Catalonia. Research at the Vallcebre area is also supported by an agreement between CSIC and the Ministerio de Medio Ambiente, Medio Rural y Marino (RESEL). 


\section{References}

ANGULO-MARTÍNEZ, M., LÓPEZ-VICENTE, M., VICENTE-SERRANO, S.M. \& BEGUERÍA, S., 2009. Mapping rainfall erosivity at a regional scale: a comparison of interpolation methods in the Ebro Basin (NE Spain). Hydrology and Earth System Sciences, 6: 417-453.

CATARI, G., 2009. Soil loss assessment in a medium sized basin in the SE Pyrenees. Ph.D. Thesis. Autonomous University of Barcelona. Barcelona. In preparation.

DE SANTOS LOUREIRO, N. \& DE AZEVEDO COUTHINO, M., 2001. A new procedure to estimate the RUSLE EI30 index, based on monthly rainfall data applied to the Algarve region, Portugal. Journal Hydrology, 250: 12-18.

DIODATO, N., 2004. Estimating RUSLE's rainfall factor in the part of Italy with a Mediterranean rainfall regime. Hydrology and Earth System Sciences, 8(1): 103-107.

DELGADO, J.M., 2006. Análisis de series hidrológicas y climáticas para su aplicación en el estudio de los efectos del cambio de uso del suelo sobre el balance hídrico en la cabecera del Llobregat. M.Sc. thesis, Autonomous University of Barcelona, Barcelona.

ELLIOT, W.J., 1995. Precipitation. In: Environmental Hydrology. Boca Raton, FL: CRC Lewis Publishers. Chap. 2, pp. 19-49.

ELLISON, W.D., 1952. Raindrop impact as the force initiating soil erosion. Soil Sci. Soc. Amer. Proc., 15: 7-10

FOSTER, G.R., 2004. Revised Universal Soil Loss Equation Version 2. User reference guide. USDA Natural Resources Conservation Service, Tennessee.

GALLART, F., LLORENS, P., LATRON, J., \& REGÜÉS, D., 2002. Hydrological processes and their seasonal controls in a small Mediterranean mountain catchment in the Pyrenees. Hydrology and Earth System Sciences, 6 (3): 527537.

GARCÍA-RUÍZ, J.M., ARNÁEZ, J., WHITE, S.M., LORENTE, A. \& BEGUERÍA, S., 2000. Uncertainty assessment in the prediction of extreme rainfall events: and example from the Central Spanish Pyrenees. Hydrology and Earth System Sciences, 14: 887-898.

HUDSON, N., 1995. Soil Conservation, 3rd Edition, Batsford Book, London, $391 \mathrm{pp}$.

ICC (INSTITUTO CATALÁN DE CARTOGRAFÍA), 2007. Mapa geológico de Cataluña. Barcelona.

INM (INSTITUTO NACIONAL DE METEOROLOGÍA), 2004. Series de precipitation. Madrid.

LATRON, J., ANDERTON, S., WHITE, S., LLORENS, P. \& GALLART, F., 2003. Seasonal characteristics of the hydrological response in a Mediterranean 
mountain research catchment (Vallcebre, Catalan Pyrenees): field investigations and modelling. Servat, E., Najem, W., Leduc, C., \& Shakeel, A. (eds), Hydrology of Mediterranean and Semiarid Regions. IAHS, 278: 106110.

LÓPEZ-VICENTE, M., NAVAS, A., \& MACHIN, J., 2008. Identifying erosive period by using RUSLE factors in mountain fields of the Central Spanish Pyrenees. Hydrology and Earth System Sciences, 12: 523-535.

MCGREGOR, K.C., BINGNER, R.L., BOWIE A.J. \& FOSTER, G.R., 1995. Erosivity index values for northern Mississippi. Transactions of the American Society of Agricultural Engineers, 38(4):1039-1047.

MOORE, T.R., 1979. Rainfall erosivity in East Africa. Geografiska Annaler, 61A: 147-156.

RENARD, K.G., FOSTER, G.R., WEESIES, G.A., MCCOOL, D.K. \& YODER, D.C., 1997. Predicting Soil Erosion by Water: A Guide to Conservation Planning with the Revised Universal Soil Loss Equation (RUSLE). Handbook No. 703. US Department of Agriculture, Washington, DC.

USON, A. \& RAMOS, M.C., 2001. An improved rainfall erosivity index obtained from experimental interrill soil losses in soils with a Mediterranean climate. Catena, 43: 293-305.

WISCHMEIER, W.H.\& SMITH, D.D., 1959. A rainfall erosion index for a universal soil loss equation. Soil. Sci. Soc. Amer. Proc., 23:246-249.

WISCHMEIER, W.H., SMITH, D.D., 1978. Predicting Rainfall Erosion Losses: A guide to conservation planning. Vol. 537: U.S.D.A. Agriculture Handbook. Washington, D.C. 